\title{
Foreign Capital Inflows and Growth of Employment In India: An Empirical Evidence from Public and Private Sector
}

\author{
Narender ${ }^{1} \&$ Raj S. Dhankar ${ }^{2}$ \\ ${ }^{1}$ Faculty of Management Studies, University of Delhi, India \\ ${ }^{2}$ Professor, Faculty of Management Studies, University of Delhi \& Vice-Chancellor, Ansal University, Gurgaon, \\ India \\ Correspondence: Narender, Faculty of Management Studies, University of Delhi, India. E-mail: \\ naren88yadav@gmail.com
}

Received: December 11, 2015

Accepted: December 29, 2015

Online Published: January 25, 2016

doi:10.5539/ijef.v8n2p189

URL: http://dx.doi.org/10.5539/ijef.v8n2p189

\begin{abstract}
The role of foreign capital in economic growth has been a burning topic of debate in countries world over including India. It is not possible for a developing country like India to grow without sufficient foreign capital inflow, technology and employment generation. The Indian government has taken many initiatives to attract foreign investment to boost the Indian economy since the liberalization process started in 1991. As a result, India has received Foreign Direct Investment (FDI) to the tune of US \$ 380215 million by the end of June 2015. This study has assessed the growth of employment in public and private sector by the flow of foreign capital, comprising of Foreign Direct Investment, Foreign Portfolio Investment (FPI), External Commercial Borrowings (ECBs), and NRI Deposits in India during the period 1991 to 2012. The study has also analyzed the trends of employment in public and private sectors of Indian economy. We find that overall foreign capital inflows, except for the FPI and NRI deposits, have a significant positive impact on the growth of private sector employment.
\end{abstract}

Keywords: foreign direct investment, foreign portfolio investment, external commercial borrowings, NRI deposits, employment

\section{Introduction}

In 1991, globalization, privatization and liberalization became the part of the Indian government policy, aimed at making the fast growing Indian economy and globally competitive. Many forms of the foreign capital inflows have emerged since then, including FPI, FDI, NRI deposits and ECBs. A series of reforms have been undertaken with respect to trade, financial sector (banking \& insurance), telecommunication, real estate, construction sector, etc. Such reforms have brought about a major boom in the market and contributed to both employment and higher GDP growth of the Indian economy. As a result, India has received FDI to the tune of US \$ 380215 million by the end of June 2015 .

India not only invites a large aggregate of foreign capital inflows, but also holds the second largest population after China in the world and thus experiences intense employment pressure. AsperWorld Bank in 2012 India's population density increased to 416 people per square kilometer from 298 people in 1991, with a labor force of 53.40 percentages of the country's total population.Such a large labor ground and the underneath employment cause India's employment pressure intensive, thus, unemployment is a huge problem, and the Indian government tries their best to embellish the employment rate.

As per World Bank in 2012 India's unemployment rate with respect to labor force participation (34 percent in between age of 15 to 24 ) raised to 10 percent. As a result given the gradually more serious employment condition in India, directing an analysis of the influence of various foreign capital inflows on employment in India is of great importance.

\section{Public and Private Sector Employment}

The representation of trends in public and private sector employment is as per Figure 1. Figure one reveals that after the liberalization, trends of employment in both sectors have been consistent till the year 2002-2003. The percentage contribution of public and private sector employment has been 70 percent and 30 percent, respectively, but after that there has been a downward trend in the public sector employment and upward trend in 
the private sector employment. The percentage contribution of these sectors has been changed to 60 and 40 percent respectively in the year 2012. Private sector employment has grown as compared to the public sector, which is a sign of expectation that employment of private sector much affected by foreign capital inflows in the Indian economy.

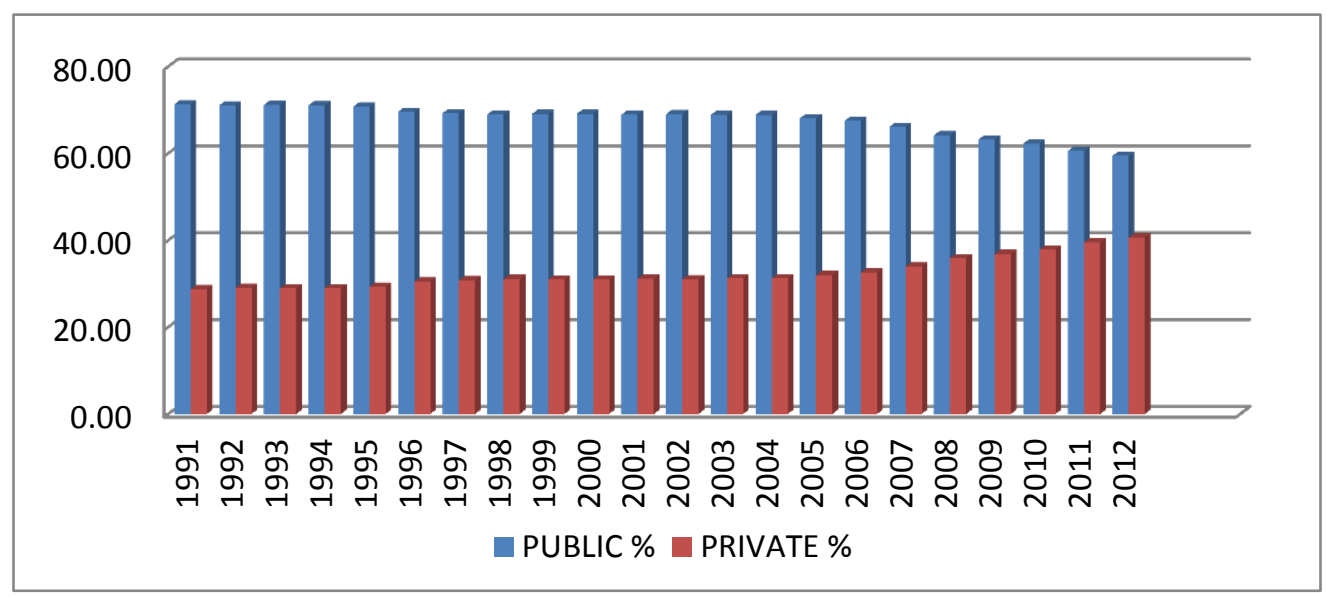

Figure 1. Trend of public and private sector employment

Source: Compiled by Author.

\section{Review of Literature}

The relationship between growth of employment and foreign investment has been a subject of discussion for many years. Craigwell (2006) examined the impact of Foreign Direct Investment on employment in the Caribbean region. The time span of this study was 1990-2000. The empirical results suggested that an increase in Foreign Direct Investment leads to greater employment in English and Dutch speaking Caribbean countries.

A study carried out by Aniceth Kato Mpanju (2012) investigated the relationship between the variable's employment and FDI by using the ordinary least square method in Tanzania. The time span of this study was 1990-2008. He found that there is a strong positive relationship between the variables, i.e. Enhanced FDI inflows were associated with enhanced employment.

Rizvi and Nishat (2009) examined the impact of FDI inflows on employment levels in India, China and Pakistan. The time span of this study was 1985-2008. Using FDI, GDP and Employment this study reached that FDI did not have any direct influence on the employment generation in these economies. They found that besides FDI enhancement, other policy measures should be taken to encourage the growth of employment.

Wang and Zhang (2005) examined the impact of FDI on Employment, based on both and macro and micro economic theory. The time period of study was 1983-2002. The study analyzed that FDI has a direct positive and indirect negative effect on employment. However, selecting a wide consideration, Impact of FDI on employment has a significant positive, with a 1 percent increase in FDI promotes to an increase of 0.008 percent in employment.

Sarwar and Habib (2013) examined the effect of Foreign Direct Investment on employment in Pakistan. The sample consisted of time series data from the years 1970 to 2011. The variables analyzed in this study were FDI, GDP per capita, employment and exchange rate. The study implemented Johansen test of Co-integration to analyze the long run relationship between the variables and results of the study revealed that FDI has a positive significant impact on employment.

Mou Jun Lin (2007) analyzed the impact of Foreign Direct Investment on employment level in China during the time period of 1984-2005. Mou argued that in the initial stage, FDI comes with a significant positive impact on employment, but later is relatively weak due to the competitive status of domestic enterprises. As per study, the negative effects of FDI on job creation are furthermore eminent and also found that after 1993, the positive impact of FDI on employment declined and become non significant.

Waldkirch et al. (2010) investigated the relationship between FDI and employment in Mexico. The study covered two hundred manufacturing units in Mexico and reached that FDI had a significantly positive impact on 
employment in the manufacturing sector.

We, therefore, find that studies have analyzed only the relationship of FDI as a foreign inflow variable to various macro economic variables rather than other sources of foreign capital like FPI, ECBs and NRI deposits. Hence, we formulate a model where the growth of Public and Private sector employment depends on the flow of FDI, FPI, ECBs and NRI deposits in India.

\section{Hypothesis Formulation}

The following hypotheses have been tested:

$\mathrm{HO}_{1}$ : There is no significant relationship between foreign inflow variables and total employment.

$\mathrm{H} 1_{1}$ : There is a significant relationship between foreign inflow variables and total employment.

$\mathrm{HO}_{2}$ : There is no significant relationship between foreign inflow variables and private employment.

$\mathrm{H}_{2}$ : There is a significant relationship between foreign inflow variables and private employment.

$\mathrm{H}_{3}$ : There is no significant relationship between foreign inflow variables and public employment.

$\mathrm{H1}_{3}$ : There is a significant relationship between foreign inflow variables and public employment.

\subsection{Model Formulation}

$$
\begin{gathered}
\text { TTLEMP }_{t}=\beta_{0}+\beta_{1} F D I_{t-1}+\beta_{2} F P I_{t-1}+\beta_{3} E C B_{t-1}+\beta_{4} N R I_{t-1}+\beta_{5} G D P_{t-1}+\beta_{6} G E X P_{t-1}+\beta_{7} P P L G R W_{t-1}+\beta_{8} L I T_{t-1}+e_{t} \\
\text { PRIEMP }_{t}=\beta_{0}+\beta_{1} F D I_{t-1}+\beta_{2} F P I_{t-1}+\beta_{3} E C B_{t-1}+\beta_{4} N R I_{t-1}+\beta_{5} G D P_{t-1}+\beta_{6} G E X P_{t-1}+\beta_{7} G F C F_{t-1}+\beta_{8} P P L G R W_{t-1}+ \\
\beta_{9} L I T_{t-1}+e_{t} \\
P U B E M P_{t}=\beta_{0}+\beta_{1} F D I_{t-1}+\beta_{2} F P I_{t-1}+\beta_{3} E C B_{t-1}+\beta_{4} N R I_{t-1}+\beta_{5} G D P_{t-1}+\beta_{6} G E X P_{t-1}+\beta_{7} G F C F_{t-1}+ \\
\beta_{8} P P L G R W_{t-1}+\beta_{9} L I T_{t-1}+e_{t}
\end{gathered}
$$

Whereas

FDI = Foreign direct investment;

FPI = Foreign portfolio investment;

$\mathrm{ECB}=$ External commercial borrowings;

NRI = Non resident of India deposits;

TTLEMP = Total employment;

PRIEMP = Private employment;

PUBEMP = Public employment.

\subsection{Data Collection and Research Methodology}

The data set of foreign capital inflow consists of different variables like FDI, FPI, ECB and NRI which are a function of total employment, private employment and public employment. The data set is secondary and covers the time period after the liberalization of Indian economy for the year 2012. Data has been collected from the department of industrial policy and promotion, economic survey reports, and annual publications of Reserve Bank of India.

We used Unit root test, Johansen Co-integration test and Ordinary least square research techniques to test the statistical significance of the association between FDI, FPI, ECB, NRI and Employment of Indian economy. These techniques help to measure the strength and direction of association between variables.

\section{Analysis}

Table-1 presents the descriptive statistics of the selected variables. During the period 1991-2012 India's average GDP at market price was US \$ 708559 million. The average inflow of FDI during this period was US \$ 6079.86 million. The description of overall foreign inflows shows that during the period under consideration average foreign inflows was US \$ 18141 million, which was more than 3 percent of average GDP. The average value of total employment was closely 3 times of average private employment value during the liberalization period. 
Table 1. Descriptive statistics

\begin{tabular}{ccccccccc}
\hline & FDI & FPI & ECB & NRI & GDP & TTLEMP & PRIEMP & PUBEMP \\
\hline Mean & 6079.86 & 7156.55 & 33985.27 & 25342.68 & 708559.60 & 27.66 & 8.98 & 18.68 \\
Median & 3125.50 & 3169.50 & 22239.50 & 16861.00 & 483584.00 & 27.54 & 8.65 & 18.92 \\
Maximum & 22372.00 & 32396.00 & 120136.00 & 58608.00 & 1880154.00 & 29.65 & 12.04 & 19.56 \\
Minimum & 97.00 & 14030.00 & 10209.00 & 10083.00 & 252807.00 & 26.45 & 7.68 & 17.55 \\
Std. Dev. & 7100.73 & 11074.70 & 30373.41 & 16070.91 & 481350.60 & 0.81 & 1.20 & 0.74 \\
Skewness & 1.36 & 0.94 & 1.64 & 0.65 & 1.16 & 0.60 & 1.30 & -0.27 \\
Kurtosis & 3.38 & 3.61 & 4.66 & 1.95 & 3.17 & 2.98 & 3.66 & 1.41 \\
Jarque-Bera & 6.90 & 3.58 & 12.38 & 2.54 & 5.04 & 1.33 & 6.63 & 2.58 \\
Probabiliy & 0.03 & 0.17 & 0.00 & 0.28 & 0.08 & 0.51 & 0.04 & 0.28 \\
\hline
\end{tabular}

\subsection{Unit Root Test}

Results of Augmented Dickey Fuller test (ADF) and Phillip-Person (PP) Tests applied to time series show that all series belong to employment and foreign capital inflows indicators are not stationary at level. To make that series stationary, first differences of the series have been taken. Table 2 depicts the results of ADF and PP statistics for all the variables. The test statistics of PP test, which are more appropriate, show statistically significant for all the variables under consideration. It confirms that the variables have no unit root when a year lag is considered to check the dependency of employment. Therefore, all the variables under consideration are stationary.

Table 2. Unit root test

\begin{tabular}{ccccc}
\hline \multirow{2}{*}{ Variables } & \multicolumn{2}{c}{ ADF } & At Levels & First Differences \\
\cline { 2 - 5 } & At Levels & First Differences & -2.18 & $-7.37^{*}$ \\
FDI & -2.22 & $-4.82^{*}$ & $-6.53^{*}$ & $-28.48^{*}$ \\
FPI & $-6.53^{*}$ & $-3.99^{* *}$ & -3.14 & $-10.69^{*}$ \\
ECB & -3.22 & $-4.81^{*}$ & 6.67 & $-1.83^{* * *}$ \\
NRI & 3.57 & 2.90 & -1.02 & $-5.64^{* * *}$ \\
TTLEMP & -2.58 & -1.95 & -2.71 & $-3.64^{*}$ \\
PUBEMP & -2.22 & -1.17 & 0.11 & $-5.27^{* * *}$ \\
PRIEMP & -0.84 & -1.91 & -1.49 & $-3.52^{* *}$ \\
GDP & -1.49 & $-4.58^{*}$ & -1.74 & $-3.99^{* *}$ \\
GFCF & -1.62 & $-3.99^{* *}$ & -2.72 & $-3.23^{* * *}$ \\
GEXP & -1.77 & $-4.04^{* *}$ & -0.94 & $-5.55^{*}$ \\
LITR & -1.03 & $-5.64 *$ & -1.20 & $-1.10^{* * *}$ \\
PPLGRW & -1.59 & -0.64 & &
\end{tabular}

Note. *,**,** Significant at $1 \%, 5 \%, 10 \%$ level respectively.

\subsection{Johansen Co-Integration Test}

Table 3, 4 and 5 show the results of Johansen test for the long relationship between foreign capital and growth of employment. The Trace and Max-Eigen test rejects the null hypothesis if these statistics exceed the critical value. The first row of table 3 shows that the Eigen statistics (69.79) exceeds the critical value of (33.87) and Trace statistics (168.16) exceeds the critical value of (69.81) at 95 percent confidence level. Similarly, for private and public sector employment in Table 4 and 5, the trace statistics exceeds the critical value of at 95 percent confidence level. It suggests that the null hypothesis of no co integrating relationships is rejected. The results confirm that there is a co integrating relationship among the variables.

Table 3. Johansen's test for employment

\begin{tabular}{ccccc}
\hline Hypothesis & Eigen statistics & Critical Values & Trace statistics & Critical values \\
\hline$r_{0}$ & $69.79^{*}$ & 33.87 & $168.18^{*}$ & 69.81 \\
$\mathrm{r}_{1}$ & $50.75^{*}$ & 27.58 & $98.39^{*}$ & 47.85 \\
$\mathrm{r}_{2}$ & 22.28 & 21.13 & $47.63^{*}$ & 29.79 \\
$\mathrm{r}_{3}$ & 19.35 & 14.26 & 25.34 & 15.49 \\
$\mathrm{r}_{4}$ & 5.99 & 3.84 & 5.99 & 3.84 \\
\hline
\end{tabular}

* Significant at $5 \%$ level. 
Table 4. Johansen's test for private employment

\begin{tabular}{ccccc}
\hline Hypothesis & Eigen statistics & Critical Values & Trace statistics & Critical values \\
\hline $\mathrm{r}_{0}$ & $53.17^{*}$ & 33.87 & $136.89^{*}$ & 69.81 \\
$\mathrm{r}_{1}$ & $46.37^{*}$ & 27.58 & $83.72^{*}$ & 47.85 \\
$\mathrm{r}_{2}$ & 19.79 & 21.13 & $37.34^{*}$ & 29.79 \\
$\mathrm{r}_{3}$ & 14.41 & 14.26 & 17.55 & 15.49 \\
$\mathrm{r}_{4}$ & 3.13 & 3.84 & 3.13 & 3.84 \\
\hline
\end{tabular}

*Significant at $5 \%$ level.

Table 5. Johansen's test for public employment

\begin{tabular}{ccccc}
\hline Hypothesis & Eigen statistics & Critical Values & Trace statistics & Critical values \\
\hline $\mathrm{r}_{0}$ & $65.49^{*}$ & 33.87 & $155.89^{*}$ & 69.81 \\
$\mathrm{r}_{1}$ & $36.70^{*}$ & 27.58 & $90.39^{*}$ & 47.85 \\
$\mathrm{r}_{2}$ & $23.31^{*}$ & 21.13 & $53.69^{*}$ & 29.79 \\
$\mathrm{r}_{3}$ & 18.55 & 14.26 & 30.38 & 15.49 \\
$\mathrm{r}_{4}$ & 11.83 & 3.84 & 11.83 & 3.84 \\
\hline
\end{tabular}

* Significant at $5 \%$ level.

\subsection{Overall Impact of FDI on Total Employment}

In order to study the impact of foreign capital inflows on overall employment, several regression models have been estimated. It is evident from table 6 that among all the 5 models, only 2 models show Foreign direct investment (FDI) and External commercial borrowings (ECB) have a positive and significant impact on overall employment. Foreign portfolio investment (FPI) and GDP have not a significant impact on the growth of employment, but NRI deposits has a negative and significant impact (at the 1 percent level). Whereas Government expenditure (GEXP) on infrastructure and, Literacy rate (LIT) has a positive and significant impact. Further clarifying the impact of foreign inflow variables on private and public sector employment, different models have been initiated by equation 2 and 3

Table 6. Dependent variable TTLEMP

\begin{tabular}{|c|c|c|c|c|c|}
\hline \multicolumn{6}{|c|}{ Coefficients } \\
\hline Variables & 1 & 2 & 3 & 4 & 5 \\
\hline \multirow{2}{*}{ FDI } & 1.98 & 2.00 & $5.80 *$ & 2.12 & 5.41 ** \\
\hline & $(1.96)$ & $(1.89)$ & $(2.05)$ & $(1.87)$ & $(2.54)$ \\
\hline \multirow{2}{*}{ FPI } & 7.16 & 1.19 & 1.25 & 1.04 & - \\
\hline & (1.13) & $(1.06)$ & $(1.18)$ & (1.07) & \\
\hline \multirow{2}{*}{$\mathrm{ECB}$} & 1.97 & $3.66^{*}$ & & $4.40^{*}$ & - \\
\hline & (2.03) & $(8.84)$ & - & $(1.20)$ & - \\
\hline \multirow{2}{*}{ NRI } & $-0.00 *$ & $-0.00 *$ & & $-0.00 *$ & \\
\hline & $(2.74)$ & $(1.96)$ & - & $(3.20)$ & - \\
\hline \multirow{2}{*}{ GDP } & 2.41 & & & & 1.07 \\
\hline & $(2.21)$ & - & 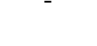 & 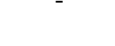 & $(1.11)$ \\
\hline \multirow{2}{*}{ GEXP } & - & 0.18 & $0.42 * *$ & - & $0.43 * * *$ \\
\hline & - & $(0.14)$ & $(0.18)$ & - & $(0.24)$ \\
\hline \multirow{2}{*}{ LIT } & 0.03 & 0.04 & $0.45^{*}$ & - & $0.43^{*}$ \\
\hline & $(0.02)$ & $(0.02)$ & $(0.11)$ & - & $(0.12)$ \\
\hline \multirow{2}{*}{ PPLGRW } & - & - & $18.46^{*}$ & $-2.15 * * *$ & $17.52 *$ \\
\hline & & & $(4.08)$ & (1.11) & $(4.27)$ \\
\hline \multirow{2}{*}{$\mathrm{C}$} & 25.67 & 6.97 & -73.87 & 31.92 & -71.81 \\
\hline & $(1.32)$ & (14.74) & (26.56) & (3.16) & (33.32) \\
\hline $\mathrm{R}^{2}$ & 0.84 & 0.85 & 0.74 & 0.84 & 0.72 \\
\hline A. $R^{2}$ & 0.78 & 0.79 & 0.66 & 0.78 & 0.63 \\
\hline D.W & 1.58 & 1.88 & 1.25 & 1.47 & 1.29 \\
\hline Prob (F-stat) & 0.000 & 0.000 & 0.000 & 0.000 & 0.000 \\
\hline
\end{tabular}

\footnotetext{
* significant at $1 \%$ level, ${ }^{* *}$ significant at $5 \%$ level, ${ }^{* * *}$ significant at $10 \%$ level, () standard error value.
} 


\subsection{Overall Impact of FDI on Private Employment}

Table 7 shows that only FDI has a strong positive and significant effect on private employment as compared to overall employment. ECB, LIT, GEXP and GDP also have positive and significant (at the 1 percent level) impact on private sector employment. NRI deposits and Foreign portfolio investment (FPI) have not much impact on employment of private sector. With respect to model 5, FDI, GDP, LIT and Population growth (PPLGRW) have been estimated to have a positive and significant (at the 5 percent and 1 percent levels respectively) impact.

Table 7. Dependent variable PRIEMP

\begin{tabular}{|c|c|c|c|c|c|}
\hline \multicolumn{6}{|c|}{ Coefficients } \\
\hline Variables & 1 & 2 & 3 & 4 & 5 \\
\hline \multirow{2}{*}{ FDI } & 1.24 & $2.57 * *$ & $3.50 * *$ & $2.85^{*}$ & $4.16^{* *}$ \\
\hline & (1.14) & $(1.11)$ & $(1.36)$ & (1.03) & $(1.62)$ \\
\hline \multirow{2}{*}{ FPI } & -5.08 & 7.16 & $1.37 * *$ & 7.30 & 3.27 \\
\hline & $(6.58)$ & (6.34) & $(5.55)$ & $(6.24)$ & $(8.21)$ \\
\hline \multirow{2}{*}{ ECB } & 2.31 & $3.58^{*}$ & & $3.21^{*}$ & \\
\hline & (1.17) & (7.11) & - & $(5.01)$ & - \\
\hline \multirow{2}{*}{ NRI } & $-5.36^{*}$ & $-4.71 * *$ & & $-3.60 *$ & 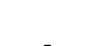 \\
\hline & (1.62) & $(1.85)$ & $\begin{array}{c}- \\
-\end{array}$ & (1.09) & - \\
\hline \multirow{2}{*}{ GDP } & $3.59 *$ & & & & $1.94 *$ \\
\hline & $(1.26)$ & - & - & - & $(5.89)$ \\
\hline \multirow{2}{*}{ GFCF } & - & 0.03 & $-0.15^{* *}$ & - & - \\
\hline & & $(0.04)$ & $(0.06)$ & & - \\
\hline \multirow{2}{*}{ GEXP } & & & $0.46^{*}$ & & \\
\hline & - & 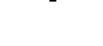 & $(0.09)$ & 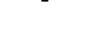 & 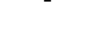 \\
\hline \multirow{2}{*}{ LIT } & - & $0.04 *$ & 0.10 & $0.04 *$ & $0.20 *$ \\
\hline & - & $(0.01)$ & (0.09) & $(0.01)$ & $(0.06)$ \\
\hline \multirow{2}{*}{ PPLGRW } & - & - & 2.30 & - & $7.49 *$ \\
\hline & & & $(4.08)$ & & $(2.15)$ \\
\hline \multirow{2}{*}{$\mathrm{C}$} & 7.56 & 4.99 & -44.67 & 5.58 & -17.18 \\
\hline & $(0.18)$ & (1.11) & (15.39) & $(0.76)$ & $(7.22)$ \\
\hline $\mathrm{R}^{2}$ & 0.97 & 0.97 & 0.97 & 0.97 & 0.96 \\
\hline A. $R^{2}$ & 0.96 & 0.96 & 0.96 & 0.96 & 0.94 \\
\hline D.W & 1.32 & 1.44 & 2.20 & 1.24 & 0.84 \\
\hline Prob (F-stat) & 0.000 & 0.000 & 0.000 & 0.000 & 0.000 \\
\hline
\end{tabular}

$*$ significant at $1 \%$ level, ${ }^{* *}$ significant at $5 \%$ level, $* * *$ significant at $10 \%$ level, () standard error value.

\subsection{Overall Impact of FDI on Public Employment}

Now, another aspect of employment, i.e., Public sector employment data have been initiated by five regression models in Table 8. It is evident from Table 8 that foreign capital inflow variables don't have a significant impact on public sector employment. Both, Literacy rate and NRI deposits have negative and significant effect at the 1 percent level.

Table 8. Dependent variable PUBEMP

\begin{tabular}{cccccc}
\hline & \multicolumn{7}{c}{ Coefficients } & & \\
\hline Variables & 1 & 2 & 3 & 4 & 5 \\
\hline \multirow{2}{*}{ FDI } & 1.21 & -2.00 & 1.07 & -9.96 & 4.14 \\
& $(1.00)$ & $(1.02)$ & $(9.99)$ & $(6.26)$ & $(1.07)$ \\
\multirow{2}{*}{ FPI } & 4.02 & 3.97 & 3.90 & -4.10 & 7.74 \\
& $(5.75)$ & $(5.74)$ & $(0.67)$ & $(6.29)$ & $(6.38)$ \\
\multirow{2}{*}{ ECB } & 9.47 & 6.74 & 6.52 & - & -2.98 \\
& $(1.02)$ & $(4.79)$ & $(6.43)$ & & $(1.62)$ \\
\multirow{2}{*}{ NRI } & $-5.66^{*}$ & $-6.15^{*}$ & $-5.73^{*}$ & - & - \\
& $(1.41)$ & $(1.06)$ & $(1.71)$ & - & \\
\hline
\end{tabular}




\begin{tabular}{|c|c|c|c|c|c|}
\hline GDP & $\begin{array}{c}-2.25 \\
(1.10)\end{array}$ & - & - & - & $\begin{array}{c}-1.74 \\
(1.37)\end{array}$ \\
\hline GFCF & - & - & $\begin{array}{l}-0.01 \\
(0.04)\end{array}$ & $\begin{array}{l}-0.11^{*} \\
(0.02)\end{array}$ & $\begin{array}{c}-0.17^{*} \\
(0.04)\end{array}$ \\
\hline GEXP & - & $\begin{array}{c}0.05 \\
(0.08)\end{array}$ & - & - & $\begin{array}{l}0.38 * \\
(0.11)\end{array}$ \\
\hline LIT & - & $\begin{array}{l}-0.00 * \\
(0.01)\end{array}$ & - & $\begin{array}{c}-0.01 * \\
(0.01)\end{array}$ & $\begin{array}{c}0.00 \\
(0.01)\end{array}$ \\
\hline PPLGRW & - & - & $\begin{array}{l}-0.18 \\
(0.59)\end{array}$ & - & - \\
\hline $\mathrm{C}$ & $\begin{array}{l}19.91 \\
(0.15)\end{array}$ & $\begin{array}{r}14.80 \\
(7.97)\end{array}$ & $\begin{array}{l}20.52 \\
(1.69)\end{array}$ & $\begin{array}{l}22.65 \\
(0.78)\end{array}$ & $\begin{array}{l}-14.77 \\
(11.01)\end{array}$ \\
\hline $\mathrm{R}^{2}$ & 0.94 & 0.94 & 0.94 & 0.90 & 0.94 \\
\hline A. $R^{2}$ & 0.92 & 0.92 & 0.92 & 0.87 & 0.92 \\
\hline D.W & 1.41 & 1.72 & 1.42 & 0.69 & 2.02 \\
\hline Prob (F-stat) & 0.000 & 0.000 & 0.000 & 0.000 & 0.000 \\
\hline
\end{tabular}

* significant at $1 \%$ level,** significant at $5 \%$ level, *** significant at $10 \%$ level, () standard error value.

\section{Conclusion}

This study has examined the impact of selected explanatory variables, namely FDI, FPI, ECB, NRI and GDP with literacy rate and population growth on employment in public and private sectors of India. Our result showed that the only FDI and ECB are playing a significant role in an unemployment reduction in the private sector of India. However, foreign capital inflows are not doing significant help to raise the employment in the public sector. Due to the inflow of ECB, such as inflow acts as government expenditure on infrastructure and education, hence resulting in reduction of unemployment in the country. Government should focus about FDI, which could also create more domestic jobs and strengthen economic growth. Government should also concern on other measures like literacy rate besides FDI and ECB to increase employment possibilities and boost economic development.

India has a 68 percent literacy rate with a labor force of 53.40 percent of the country's total population. Such a large labor ground and the underneath employment cause India's employment pressure intensifies. In order for having better employment rate and economy to be successful, effective measures should be taken by the Indian government with foreign investment to provide better skills of the labor force so that they can absorb themselves in a modern environment.

\section{References}

Craigwell, R. (2006). Foreign Direct Investment and Employment in the English and Dutch Speaking Caribbean. Working Papers, Tripartite Caribbean Employment Forum, Barbados.

Department of industrial policy \& promotion, GOI, FDIStatistics.

Dhankar, R. S. (1993). Foreign Direct Investment in the Changing Global Scenario and its Implications for Developing Countries. Finance India, 2(3), 9-32.

Habib, M. D., \& Sarwar, S. (2013). Impact of Foreign Direct Investment on Employment Level In Pakistan: A Time Series Analysis. Journal of Law, Policy and Globalization, 10, 46-55.

Jun-lin, M. (2007). An Empirical Study on the Effects of FDI on the Employment in China. Economy and Management, 4.

Mpanju, A. K. (2012). The impact of foreign direct investment on employment creation in Tanzania. ZENITH International Journal of Business Economics \& Management Research, 2(1), 126-139.

Narender, \& Dhankar, R. S. (2015). Composition of Foreign capital inflows and growth in India: An Empirical Analysis. International Journal of Management Sciences and Business Research, 4(4), $26-32$.

Narender. (2015). Composition of foreign direct investment in India: A Route wise analysis. International Journal of Research in Computer Application \& Management, 5(5), 89-92.

Nayyra, Z., Qiang, F., \& Muhammad, S. S. (2014). Foreign direct Investment and unemployment reduction in Pakistan. International Journal of Economic Research, 5(2), 10-17. 
Rizvi, S. Z. A., \& Nishat, M. (2009). The Impact of Foreign Direct Investment on Employment Opportunities: Panel Data Analysis: Empirical Evidence from Pakistan, India and China. Retrieved from http://www.pide.org.pk/pdf/PDR/2009/Volume4/841-851.pdf

Waldkirch, A., Nunnenkamp, P., \& Bremont, J. E. A. (2010). FDI in Mexico: An empirical assessment of employment effects. Journal of Development Studies, 45(7), 1165-1183. http://dx.doi.org/10.1080/00220380902952340

Wang, J., \& Zhang, H. (2005). An empirical study of effect of foreign direct investment on China's employment. World Economy Study, 9, 15-21.

Wei, Y. (2013). The effect of FDI on employment in China. Graduate Theses and Dissertations. Paper 13379.

\section{Copyrights}

Copyright for this article is retained by the author(s), with first publication rights granted to the journal.

This is an open-access article distributed under the terms and conditions of the Creative Commons Attribution license (http://creativecommons.org/licenses/by/3.0/). 